
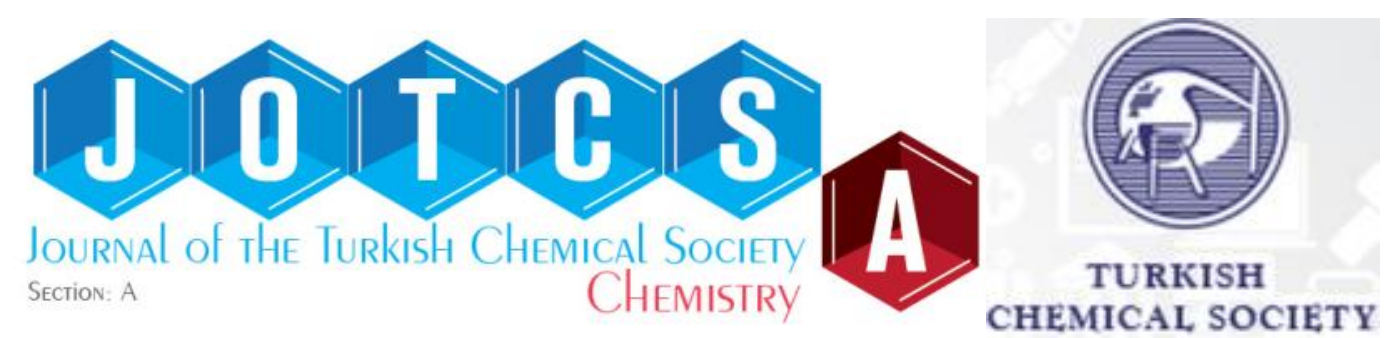

\title{
Synthesis, Characterization and Optimum Reaction Conditions of Oligo-N-Salicylidenephenylhydrazone via Oxidative Polymerization
}

\author{
Feyza Kolcu
}

\author{
Çanakkale Onsekiz Mart University, Lapseki Vocational School, Department of Chemistry and \\ Chemical Processing Technologies, Çanakkale, Turkey
}

Abstract: The oxidative polycondensation conditions and optimum parameters of $\mathrm{N}$ salicylidenephenylhydrazone (SPH) were determined using air, $\mathrm{H}_{2} \mathrm{O}_{2}$ and $\mathrm{NaOCl}$ as oxidants at a temperature range between $50{ }^{\circ} \mathrm{C}$ and $95{ }^{\circ} \mathrm{C}$ in an aqueous alkaline medium. The molecular structures of the obtained monomer and oligomer were confirmed by FT-IR, UV-Vis, ${ }^{1} \mathrm{H}-\mathrm{NMR}$ and elemental analyses. The molecular weight distributions of oligo- $\mathrm{N}$-salicylidenephenylhydrazone were determined (OSPH) by SEC measurement. Thermal behavior (TG-DTA) of OSPH was examined using thermogravimetric techniques. The conversion of $\mathrm{N}$-salicylidenephenylhydrazone into its oligomeric form was performed using air, $\mathrm{H}_{2} \mathrm{O}_{2}$ and $\mathrm{NaOCl}$ as oxidants in an aqueous alkaline medium. According to SEC analysis, the number-average molecular weight $\left(M_{n}\right)$, weight-average molecular weight $\left(M_{w}\right)$ and polydispersity index (PDI) values of OSPH obtained using $\mathrm{NaOCl}$ oxidant were found to be 1436 $\mathrm{g} \mathrm{mol}^{-1}, 1631 \mathrm{~g} \mathrm{~mol}^{-1}$ and 1.14 , respectively. The conversion yield of $\mathrm{N}$-salicylidenephenylhydrazone into oligo- $\mathrm{N}$-salicylidenephenylhydrazone was $100 \%$ at optimum reaction conditions such as [SPH] $=[\mathrm{KOH}]_{0}=\left[\mathrm{H}_{2} \mathrm{O}_{2}\right]_{0}=0.06 \mathrm{~mol} / \mathrm{L}$ and at $90^{\circ} \mathrm{C}$ for $10 \mathrm{~h}$. Also, according to TG-DTA analysis, oligo- $\mathrm{N}-$ salicylidenephenylhydrazone was shown to be thermally stable and resistant to thermo-oxidative decomposition. The weight loss of OSPH was found to be 20,50 and $92.56 \%$ at $275^{\circ}, 597^{\circ}$ and 1000 ${ }^{\circ} \mathrm{C}$, respectively.

Keywords: oligo-N-salicylidenephenylhydrazone, oxidative polycondensation, reaction conditions, thermo-oxidative decomposition.

Submitted: January 3, 2018. Accepted: July 23, 2018.

Cite this: Kolcu F. Synthesis, Characterization and Optimum Reaction Conditions of Oligo-NSalicylidenephenylhydrazone via Oxidative Polymerization. JOTCSA. 2018;5(2):919-30.

\section{DOI:}

*Corresponding author. E mail: feyzakolcu@comu.edu.tr, Fax: +90-286-522 6101

\section{INTRODUCTION}

The oligo-phenols and their Schiff base derivatives including $-\mathrm{OH}$ and $-\mathrm{CH}=\mathrm{N}$ groups have been used in various fields. They have useful properties such as paramagnetism, semi conductivity, employed in electrochemical cells and they resist to high energy (1-4). Polymer-metal complex compounds can be prepared with the reaction of metal salts and polymers containing electron donor groups such as $-\mathrm{OH}$ and $\mathrm{CH}=\mathrm{N}$ (5). Antimicrobial properties of oligophenols with Schiff base substitute and their oligomer-metal complex compounds were investigated by Kaya et al $(6,7)$. Oligophenols may be used in cleaning poisonous heavy metals in the industrial wastewaters. Also, Schiff base compounds have been used to determine the transition metals in some natural food samples (8). Therefore, the syntheses of oligomer and oligomer-metal complexes are very important for analytical, environmental and food chemistry. 
All azomethine polymers show a remarkable thermal stability. Non-conjugated polymers are white or cream colored and have thermal stabilities at about $300{ }^{\circ} \mathrm{C}$ in $\mathrm{N}_{2}$ and $250{ }^{\circ} \mathrm{C}$ in air atmosphere. The color of aromatic azomethine polymers changes from yelloworange to red-brown or black products, with thermal stabilities up to $500-550{ }^{\circ} \mathrm{C}$ in $\mathrm{N}_{2}$ and $430-480{ }^{\circ} \mathrm{C}$ in air atmosphere. They are also resistant to radiation and their stability is found to be independent of dose rate and nature of the ionizing radiation (9).

In this study, we have investigated the effects of different parameters such as temperature, initial concentrations of $\mathrm{NaOCl}, \mathrm{H}_{2} \mathrm{O}_{2}$ and $\mathrm{KOH}$ for the polymerization of $\mathrm{N}$ salicylidenephenylhydrazone. The molecular structures of the obtained monomer and oligomer were confirmed by using FT-IR, UVVis, ${ }^{1} \mathrm{H}-\mathrm{NMR}$, elemental analyses. Additionally, OSPH was characterized by TG-DTA, SEC, and solubility tests.

\section{MATERIALS AND METHODS}

\section{Materials}

Phenylhydrazine, salicylaldehyde (SA), 1,4dioxane, ethanol, methanol, benzene, acetone, ethyl acetate, n-heptane, tetrahydrofuran (THF), dimethylsulfoxide (DMSO), N, N'-dimethylformamide (DMF), $\mathrm{H}_{2} \mathrm{SO}_{4}$, toluene, pyridine, n-hexane, hydrochloric acid $(\mathrm{HCl})(37 \%)$ and $\mathrm{H}_{2} \mathrm{O}_{2}(35 \%$ solution in water) were supplied from Merck Chemical Co. (Germany) and they were used as received. Sodium hypochlorite $(\mathrm{NaOCl})$, (30\% solution in water) was supplied from Paksoy Chem. Co. (Turkey).

\section{Preparation of salicylidenephenylhydrazone (SPH)} $\mathrm{N}$-salicylidenephenylhydrazone (SPH) was prepared by the condensation of salicylaldehyde $(0.025 \mathrm{~mol})$ and phenylhydrazine $(0.025 \mathrm{~mol})$ in $25-\mathrm{mL}$ methanol under reflux for $3 \mathrm{~h}$ (Scheme 1). The precipitated $\mathrm{N}$-salicylidenephenylhydrazone $(\mathrm{SPH})$ was filtered and recrystallized from methanol and dried in a vacuum desiccator (m.p.: $125^{\circ} \mathrm{C}$, yield, 90\%).

Anal. calcd. for SPH: C, 73.59; $H, 5.66 ; N$, 13.21. Found: $C, 73.35 ; H, 5.52 ; N, 13.12$. UV-Vis $\left(\lambda_{\max }\right): 220,236,280$ and $340 \mathrm{~nm}$. FT$I R\left(K B r, \mathrm{Cm}^{-1}\right): v(\mathrm{O}-\mathrm{H}) 3470 \mathrm{~s}, v(\mathrm{C}-\mathrm{H}$ aryl) $3030 \mathrm{~m}, v(\mathrm{C}=\mathrm{N}) 1615 \mathrm{~s}, v(\mathrm{~N}-\mathrm{H}) 3300 \mathrm{~s}, v$ $(C=C) 1580,1455,1450 \mathrm{~s}, v($ Ar-O) $1280 \mathrm{~s}$. ${ }^{1} \mathrm{H}-\mathrm{NMR}$ (DMSO): $\delta \mathrm{ppm}, 10.15(\mathrm{~s}, 1 \mathrm{H}, \mathrm{OH})$; $8.30(\mathrm{~s}, 1 \mathrm{H}, \mathrm{C} \underline{H}=\mathrm{N}) ; 5.60(\mathrm{~s}, 1 \mathrm{H}, \mathrm{N} \underline{\mathrm{H}}) ; 7.48$ (d, 1H, Ar-Ha), 6.85 (t, 1H, Ar-Hb), 7.25 (t, $1 H, A r-H c), 6.70(d, 1 H, A r-H d) 7.00(d, 2 H$,
Ar-Hee') 7.15 ( $t, 2 H$, Ar-Hff') $6.70(t, 1 H$, Ar$\mathrm{Hg}$ ).

\section{Synthesis of Oligo- N- salicylidenephenylhydrazone with air}

$\mathrm{SPH}(4.24 \mathrm{~g}, 0.02 \mathrm{~mol})$ was dissolved in an aqueous solution of $\mathrm{KOH}(10 \%)(1.12 \mathrm{~g}, 0.02$ mol) and placed into a $100 \mathrm{~mL}$ three-necked round-bottomed flask. It was fitted with a condenser, thermometer, stirrer and a glass tube was placed over condenser for air to pass through. The reaction mixture was heated at various temperatures and times. Air was passed through an aqueous solution of $\mathrm{KOH}$ $(20 \%)$ before being sent to the reaction tube to eliminate $\mathrm{CO}_{2}$ in the air. It was cooled to room temperature and then, $0.02 \mathrm{~mol}$ of $\mathrm{HCl}$ $(37 \%)$ was added to the reaction mixture. Unreacted monomer was separated from the reaction products by washing with $n$-heptane. The mixture was filtered and washed with hot water for separating it from mineral salts and dried in the oven at $110^{\circ} \mathrm{C}$

Anal. calcd. for OSPH : C, 74.29; H, 4.76; N, 13.33. Found: $C, 73.75 ; H, 4.62 ; N, 13.00$. UV-Vis $\left(\lambda_{\max }\right): 221,241,291$ and $346 \mathrm{~nm}$. FTIR $\left(\mathrm{KBr}, \mathrm{Cm}^{-1}\right): v(\mathrm{O}-\mathrm{H}) 3500 \mathrm{~s}, v(\mathrm{C}-\mathrm{H}$ aryl) $3030 \mathrm{~m}, v(C=N) 1600 \mathrm{~s}, v(\mathrm{~N}-\mathrm{H}) 3280 \mathrm{~s}, v$ $(C=C) 1500,1470 \mathrm{~s}, v(\mathrm{Ar}-\mathrm{O}) 1270 \mathrm{~s} .{ }^{1} \mathrm{H}-\mathrm{NMR}$ (DMSO): $\delta \mathrm{ppm}, 10.40$ (s, 1H, OH ); 9.20 (s, $1 \mathrm{H}, \mathrm{CH}=\mathrm{N}) ; 6.55(\mathrm{~s}, 1 \mathrm{H}, \mathrm{NH}) ; 7.30$ (s, 1H, ArHa), 6.80 (s, 1H, Ar-Hc), 6.50 (d, 2H, Ar-Hdd') 7.00 ( $t, 2 \mathrm{H}$, Ar-Hee') 6.70 ( $t, 1 \mathrm{H}, \mathrm{Ar}-\mathrm{Hf}$ ).

\section{Synthesis of Oligo-N- salicylidenephenylhydrazone with $\mathrm{NaOCl}$} OSPH was synthesized through oxidative polycondensation of $\mathrm{SPH}$ using $\mathrm{NaOCl}(30 \%)$ as the oxidant. SPH $(4.24 \mathrm{~g}, 0.02 \mathrm{~mol})$ was placed into a $50-\mathrm{mL}$ three-necked roundbottomed flask and dissolved in an aqueous solution of $\mathrm{KOH}(10 \%, 1.12 \mathrm{~g}, 0.02 \mathrm{~mol})$. The flask was connected to a condenser, a thermometer, a magnetic stirrer, and an additional funnel containing $\mathrm{NaOCl}$. After heating at $60{ }^{\circ} \mathrm{C}, \mathrm{NaOCl}(30 \%)$ was added drop wise within $20 \mathrm{~min}$. The reaction mixture was heated at various temperatures and times. The mixture was neutralized by $\mathrm{HCl}$ $(37 \%, 0.02 \mathrm{~mol})$ at room temperature. Unreacted monomer was separated from the reaction products by washing with cold $n$ heptane. The mixture was filtered and washed with hot water for separating from mineral salts and dried in the oven at $110^{\circ} \mathrm{C}$.

\section{Synthesis of Oligo-N- salicylidenephenylhydrazone with $\mathrm{H}_{2} \mathrm{O}_{2}$} $\mathrm{OSPH}$ was synthesized through oxidative polycondensation in an aqueous alkaline medium using $\mathrm{H}_{2} \mathrm{O}_{2}(35 \%)$ as the oxidant. Polymerization was performed in a $50 \mathrm{~mL}$ 
three-necked round-bottomed flask connected to a condenser, a thermometer and a magnetic stirrer, and an addition to funnel containing $\mathrm{H}_{2} \mathrm{O}_{2}$. SPH $(4.24 \mathrm{~g}, 0.02 \mathrm{~mol}$ ) was dissolved in an aqueous solution of $\mathrm{KOH}(10 \%$, $1.12 \mathrm{~g}, 0.02 \mathrm{~mol})$. After heating at $40{ }^{\circ} \mathrm{C}, \mathrm{H}_{2} \mathrm{O}_{2}$ was added drop wise within $20 \mathrm{~min}$. The reaction mixture was heated at various temperature and time. The mixture was neutralized by $\mathrm{HCl}(37 \%, 0.02 \mathrm{~mol})$ at room temperature. Unreacted monomer was separated from the reaction products using nheptane. The mixture was filtered and washed with hot water for separating from mineral salts and dried in the oven at $110^{\circ} \mathrm{C}$.

\section{Characterization Techniques}

FT-IR and UV-Vis spectra were recorded by Mattson FT-IR 8010 and UV-160 (Shimadzu), respectively. The FT-IR spectra were recorded using $\mathrm{KBr}$ disc $\left(4000-400 \mathrm{~cm}^{-1}\right)$. UV-Vis spectra of SPH and OSPH were determined using THF. Elemental analysis was carried out by a Carlo Erba 1106. OSPH was characterized by ${ }^{1} \mathrm{H}-\mathrm{NMR}$ spectra (Bruker AC FT-NMR 400 $\mathrm{MHz}$ spectrometer) and the spectra were recorded at $25^{\circ} \mathrm{C}$ using deuterated DMSO as solvent. Tetramethylsilane (TMS) was used as internal standard. Thermal data were obtained by STA 409C NETZSCH-Geratebau GmbH Thermal Analysis. TG-DTA measurements were performed between 20 and $1000^{\circ} \mathrm{C}$ (in air, rate $10^{\circ} \mathrm{C} / \mathrm{min}$ ). SEC analyses were used to investigate both size and polydispersity of the synthesized polymers that is, the ability to be able to find the molecular range distribution of the polymer molecules (PDI), as well as the number-average molecular weight $\left(M_{n}\right)$ and the average molecular weight $\left(\mathrm{M}_{\mathrm{w}}\right)$, by using a mixture of polystyrene standards (Polymer Laboratories; the peak molecular weights, Mp, between 162 and $19880 \mathrm{~g} \mathrm{~mol}^{-1}$ ) for calibration of the instrument SEC (Shimadzu 10AVp series HPLC-SEC system), and a SGX (100 $\AA$ and $7.7 \mathrm{~nm}$ diameter loading material) $3.3 \mathrm{~mm}$ i.d. $\times 300 \mathrm{~mm}$ column. DMF as eluent at a flow rate of $0.4 \mathrm{~mL} / \mathrm{min}$ was used in SEC analyses. A refractive index detector (at $25^{\circ} \mathrm{C}$ ) was used to analyze the product.

\section{RESULTS AND DISCUSSION}

Possible four main coupling modes for the polymerization of $\mathrm{N}$ salicylidenephenylhydrazone (SPH) and the general synthetic route for the synthesis of oligo-N-salicylidenephenylhydrazone (OSPH) and were identified and given in Schemes 1 and 2 respectively.

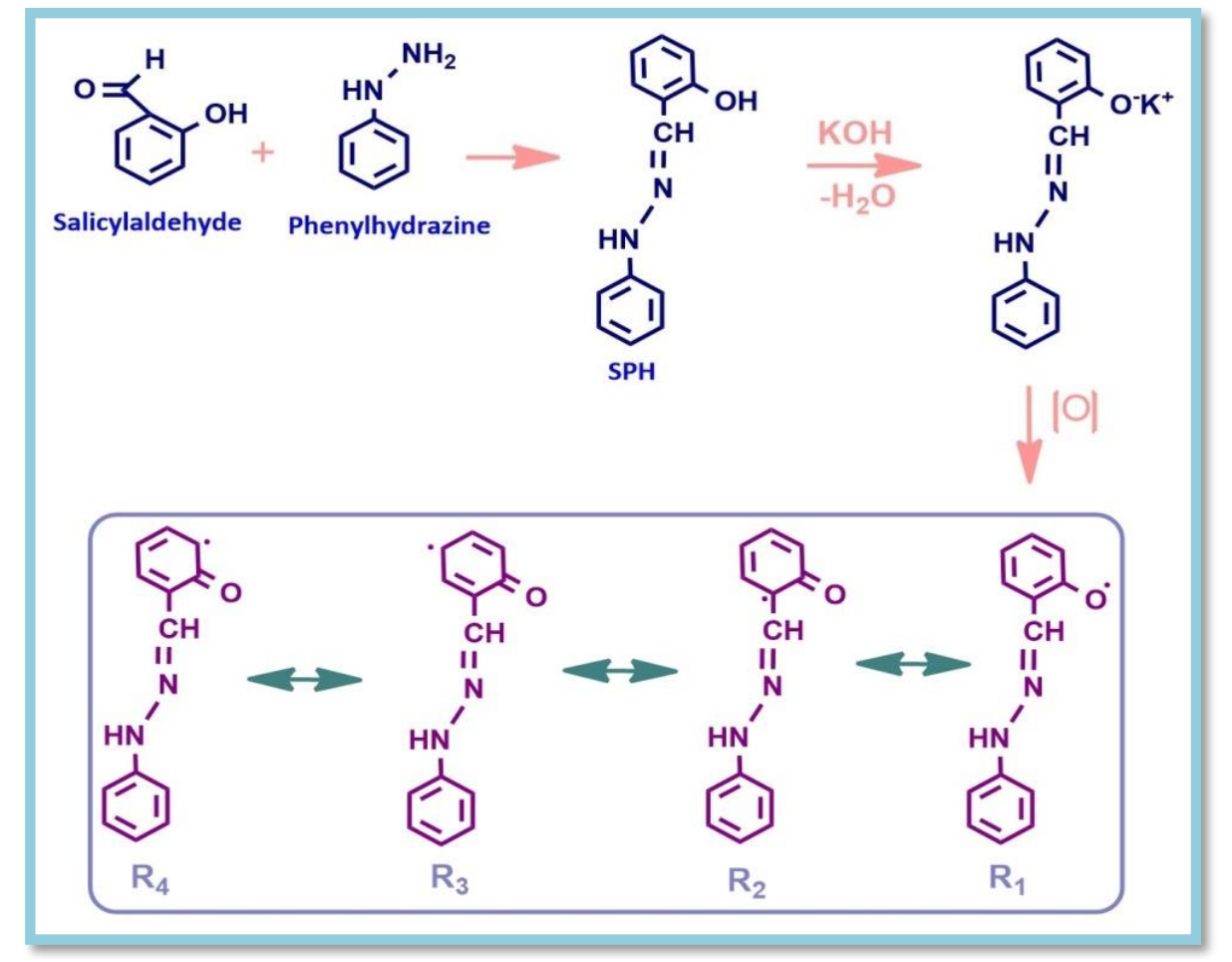

Scheme 1. Synthetic route of $\mathrm{N}$-saliciylidenehydrazone (SPH) and possible resonance and coupling modes of SPH. 




Scheme 2. Synthetic pathway of OSPH.

\section{Specifying the optimal reaction} conditions and solubility of OSPH

Oxidative polymerization of SPH was observed to be affected to different reaction parameters. To specify the optimum polycondensation conditions, polymerization of SPH was carried out using various oxidants such as $\mathrm{NaOCl}, \mathrm{H}_{2} \mathrm{O}_{2}$ and air in aqueous $\mathrm{KOH}$ solution by tuning the temperature in the range between 40 and $95^{\circ} \mathrm{C}$ at constant $\mathrm{SPH}$, $\mathrm{KOH}$ and oxidant concentration (Figure 1(a)). Additionally, the polymerization was carried out at different reaction time to assign the optimum reaction time (Figure $1(\mathrm{~b})$ ). 



Figure 1. Reaction yields of OSPH at various temperature (a) and time (b)

(Conditions: $[\mathrm{SPH}]=0.06 \mathrm{~mol} \mathrm{~L}^{-1},[\mathrm{KOH}]=0.06 \mathrm{~mol} \mathrm{~L}^{-1},[\mathrm{NaOCl}]=0.06 \mathrm{~mol} \mathrm{~L}^{-1},\left[\mathrm{H}_{2} \mathrm{O}_{2}\right]=0.06 \mathrm{~mol} \mathrm{~L}^{-1}$ and air $=8.5 \mathrm{~L} \mathrm{~h}^{-1}$ ).

The oxidative polycondensation conditions of $\mathrm{SPH}$ with air as oxidant in aqueous alkaline medium are given in Table 1 . The oxidative polycondensation of SPH was not observed in THF and acetic acid medium at various temperature and time. SPH was soluble in aqueous $\mathrm{KOH}$ but no reaction was observed when it was heated for $3 \mathrm{~h}$ at $80^{\circ} \mathrm{C}$. However, the oxidative polycondensation of SPH took place in an aqueous alkaline solution and the color turned into brown by adding oxidants such as $\mathrm{NaOCl}, \mathrm{H}_{2} \mathrm{O}_{2}$ and air. With $[\mathrm{SPH}]_{0}=$ $[\mathrm{KOH}]_{0}=0.06 \mathrm{~mol} / \mathrm{L}$, the yield of OSPH was $75 \%$ by air oxidant for $5 \mathrm{~h}$ at $50{ }^{\circ} \mathrm{C}$ (Table 1 ). While the yield of OSPH was $80 \%$ for $5 \mathrm{~h}$ at 60 ${ }^{\circ} \mathrm{C}$, the polymerization yield was found to be $35 \%$ for $5 \mathrm{~h}$ at $80^{\circ} \mathrm{C}$. The reason may be the disruption of the polymer into monomers at high temperatures. 
Table 1. The optimum oxidative polycondensation conditions of SPH in the aqueous alkaline medium with air oxidant.

\begin{tabular}{|c|c|c|c|c|c|c|}
\hline Run & $\begin{array}{c}{[\mathrm{SPH}]_{0}} \\
(\mathrm{~mol} / \mathrm{L})\end{array}$ & $\begin{array}{c}{[\mathrm{KOH}] \mathrm{o}} \\
(\mathrm{mol} / \mathrm{L})\end{array}$ & $\begin{array}{l}\text { Air } \\
\text { (L/h) }\end{array}$ & $\begin{array}{c}\text { Temp. } \\
\left({ }^{\circ} \mathrm{C}\right)\end{array}$ & $\begin{array}{c}\text { Time } \\
\text { (h) }\end{array}$ & Yield of SPH (\%) \\
\hline 1 & 0.06 & 0.06 & 8.5 & 50 & 5 & 75 \\
\hline 2 & 0.06 & 0.06 & 8.5 & 60 & 5 & 80 \\
\hline 3 & 0.06 & 0.06 & 8.5 & 80 & 25 & 60 \\
\hline 4 & 0.06 & 0.06 & 8.5 & 80 & 3 & 20 \\
\hline 5 & 0.06 & 0.12 & 8.5 & 80 & 5 & 35 \\
\hline 6 & 0.06 & 0.06 & 8.5 & 70 & 10 & 50 \\
\hline 7 & 0.06 & 0.06 & 8.5 & 75 & 10 & 40 \\
\hline 8 & 0.06 & 0.06 & 8.5 & 80 & 10 & 54 \\
\hline 9 & 0.06 & 0.06 & 8.5 & 85 & 10 & 35 \\
\hline 10 & 0.06 & 0.06 & 8.5 & 90 & 10 & 38 \\
\hline 11 & 0.06 & 0.06 & 8.5 & 95 & 10 & 30 \\
\hline
\end{tabular}

As seen in Table 1, the yield of oligomer depends on temperature and time variables. For air as the oxidant, the maximum yield of OSPH was observed as $80 \%$ at optimum conditions, such as $[\mathrm{SPH}]_{0}=[\mathrm{KOH}]_{0}=0.06$ $\mathrm{mol} / \mathrm{L}$ for $5 \mathrm{~h}$ at $60^{\circ} \mathrm{C}$ (Table 1 ).

The oxidative polycondensation conditions of $\mathrm{SPH}$ with $30 \% \mathrm{NaOCl}$ solution in aqueous alkaline medium are given in Table 2 . The yield of OSPH was $77 \%$ at optimum conditions such as $[\mathrm{SPH}]_{0}=[\mathrm{KOH}]_{0}=[\mathrm{NaOCl}]_{0}=0.06 \mathrm{~mol} / \mathrm{L}$ for $3 \mathrm{~h}$ at $80^{\circ} \mathrm{C}$. The yield of OSPH was $73 \%$ at the reaction conditions such as $[\mathrm{SPH}]_{0}=$ $[\mathrm{KOH}]_{0}=0.06 \mathrm{~mol} / \mathrm{L}$ and $[\mathrm{NaOCl}]_{0}=0.12$ $\mathrm{mol} / \mathrm{L}$ for $10 \mathrm{~h}$ at $90^{\circ} \mathrm{C}$. The various conditions of OSPH are given for $\mathrm{NaOCl}$ in Table 2 . 
Table 2. The optimum oxidative polycondensation conditions of SPH in the aqueous alkaline medium with $\mathrm{NaOCl}$ as the oxidant.

\begin{tabular}{|c|c|c|c|c|c|c|}
\hline Run & $\begin{array}{c}{[\mathrm{SPH}]_{0}} \\
(\mathrm{~mol} / \mathrm{L})\end{array}$ & $\begin{array}{l}{[\mathrm{KOH}]_{0}} \\
(\mathrm{~mol} / \mathrm{L})\end{array}$ & $\begin{array}{c}{[\mathrm{NaOCl}]_{0},} \\
(\mathrm{~mol} / \mathrm{L})\end{array}$ & $\begin{array}{c}\text { Temp. } \\
\left({ }^{\circ} \mathrm{C}\right)\end{array}$ & $\begin{array}{c}\text { Time } \\
\text { (h) }\end{array}$ & $\begin{array}{c}\text { Yield of SPH } \\
(\%)\end{array}$ \\
\hline 1 & 0.06 & 0.06 & 0.06 & 70 & 10 & 50 \\
\hline 2 & 0.06 & 0.06 & 0.06 & 70 & 5 & 58 \\
\hline 3 & 0.06 & 0.06 & 0.06 & 80 & 10 & 60 \\
\hline 4 & 0.06 & 0.06 & 0.06 & 80 & 5 & 62 \\
\hline 5 & 0.06 & 0.06 & 0.06 & 90 & 10 & 68 \\
\hline 6 & 0.06 & 0.06 & 0.06 & 90 & 5 & 65 \\
\hline 7 & 0.06 & 0.06 & 0.06 & 95 & 10 & 60 \\
\hline 8 & 0.06 & 0.06 & 0.06 & 95 & 5 & 55 \\
\hline 9 & 0.06 & 0.06 & 0.06 & 70 & 2 & 40 \\
\hline 10 & 0.06 & 0.06 & 0.06 & 80 & 3 & 77 \\
\hline 11 & 0.06 & 0.06 & 0.06 & 90 & 25 & 73 \\
\hline 12 & 0.06 & 0.06 & 0.12 & 90 & 10 & 73 \\
\hline 13 & 0.06 & 0.12 & 0.06 & 90 & 10 & 68 \\
\hline
\end{tabular}

The oxidative polycondensation conditions of $\mathrm{SPH}$ with $35 \% \quad \mathrm{H}_{2} \mathrm{O}_{2}$ solution in aqueous alkaline medium are given in Table 3 . The yield of OSPH was $100 \%$ at optimum conditions such as $[\mathrm{SPH}]_{0}=[\mathrm{KOH}]_{0}=\left[\mathrm{H}_{2} \mathrm{O}_{2}\right]_{0}=0.06$ $\mathrm{mol} / \mathrm{L}$ for $10 \mathrm{~h}$ at $90^{\circ} \mathrm{C}$. The polymerization of SPH was $64 \%$ at the reaction conditions such as $[\mathrm{SPH}]_{0}=[\mathrm{KOH}]_{0}=0.06 \mathrm{~mol} / \mathrm{L}$ and $[\mathrm{NaOCl}]_{0}$ $=0.12 \mathrm{~mol} / \mathrm{L}$ for $10 \mathrm{~h}$ at $95{ }^{\circ} \mathrm{C}$. While the polymerization of SPH was $100 \%$ and $75 \%$ for $10 \mathrm{~h}$ at $90{ }^{\circ} \mathrm{C}$ and for $10 \mathrm{~h}$ at $95^{\circ} \mathrm{C}$, respectively. The reason may be the disruption of the polymer into monomers at high temperatures. 
Table 3. The optimum oxidative polycondensation conditions of SPH in the aqueous alkaline medium with $\mathrm{H}_{2} \mathrm{O}_{2}$ as the oxidant.

\begin{tabular}{ccccccc}
\hline Run & $\begin{array}{c}{[\mathbf{S P H}] \mathbf{0}} \\
(\mathbf{m o l} / \mathbf{L})\end{array}$ & $\begin{array}{c}{[\mathbf{K O H}] \mathbf{0}} \\
(\mathbf{m o l} / \mathbf{L})\end{array}$ & $\begin{array}{c}{\left[\mathbf{H}_{\mathbf{2}} \mathbf{O}_{2}\right] \mathbf{0}} \\
(\mathbf{m o l} / \mathbf{L})\end{array}$ & $\begin{array}{c}\text { Temp. } \\
\left({ }^{\circ} \mathbf{C}\right)\end{array}$ & $\begin{array}{c}\text { Time } \\
\mathbf{( h )}\end{array}$ & $\begin{array}{c}\text { Yield of SPH } \\
(\%)\end{array}$ \\
\hline $\mathbf{1}$ & 0.06 & 0.06 & 0.06 & 50 & 10 & 76 \\
$\mathbf{2}$ & 0.06 & 0.06 & 0.06 & 60 & 10 & 68 \\
$\mathbf{3}$ & 0.06 & 0.06 & 0.06 & 70 & 10 & 90 \\
$\mathbf{4}$ & 0.06 & 0.06 & 0.06 & 75 & 10 & 96 \\
$\mathbf{5}$ & 0.06 & 0.06 & 0.06 & 80 & 10 & 99 \\
$\mathbf{6}$ & 0.06 & 0.06 & 0.06 & 85 & 10 & 99 \\
$\mathbf{7}$ & 0.06 & 0.06 & 0.06 & 90 & 10 & 100 \\
$\mathbf{8}$ & 0.06 & 0.06 & 0.06 & 95 & 10 & 75 \\
$\mathbf{9}$ & 0.06 & 0.06 & 0.06 & 95 & 2 & 60 \\
$\mathbf{1 0}$ & 0.06 & 0.06 & 0.06 & 95 & 25 & 46 \\
$\mathbf{1 1}$ & 0.06 & 0.06 & 0.12 & 95 & 10 & 64 \\
$\mathbf{1 2}$ & 0.06 & 0.06 & 0.06 & 75 & 5 & 70 \\
\hline
\end{tabular}

Since the growing macromolecular chain come out of solution during the polycondensation at low polymerization degrees, high molecular weight polymers can not be obtained. Oxidatively polymerized products of $\mathrm{OSPH}$ synthesized by air, $\mathrm{H}_{2} \mathrm{O}_{2}$ and $\mathrm{NaOCl}$ in aqueous alkaline medium were brown solid powders. $\mathrm{OSPH}$ was soluble in common organic solvents such as $\mathrm{CHCl}_{3}, \mathrm{DMSO}$, concentrated $\mathrm{H}_{2} \mathrm{SO}_{4}$ and aqueous $\mathrm{KOH}$, DMF, benzene, toluene, acetone, THF, ethyl acetate, 1,4-dioxane, ethanol, methanol and pyridine, but it was insoluble in $\mathrm{n}$-hexane and $\mathrm{n}$-heptane.

\section{Characterization of SPH and OSPH}

Based on the SEC chromatograms of OSPH, the calculated number-average molecular weight $\left(M_{n}\right)$, weight average molecular weight $\left(M_{w}\right)$, and polydispersity index (PDI) values were organized in Table 4. According to SEC analyses, $M_{n}, M_{w}$ and PDI values of OSPH were found to be $1436 \mathrm{~g} \mathrm{~mol}^{-1}, 1631 \mathrm{~g} \mathrm{~mol}^{-1}$ and 1.14 , respectively, for $\mathrm{NaOCl}$ oxidant. Total values delineated that $M_{n}, M_{w}$ and PDI values of OSPH were found to be $850 \mathrm{~g} \mathrm{~mol}^{-1}, 1155 \mathrm{~g}$ $\mathrm{mol}^{-1}$ and 1.36, respectively, for air as the oxidant. At the molecular weight distribution of OSPH, two fractions were observed with $93 \%$ of OSPH for the low molecular weight (for the first fraction: $M_{n}, 1418 \mathrm{~g} \mathrm{~mol}^{-1} ; M_{w}, 1650$ $\mathrm{g} \mathrm{mol}^{-1}$; PDI, 1.16), but $7 \%$ of its weight for the high molecular weight (for the second fraction: $M_{n}, 37632 \mathrm{~g} \mathrm{~mol}^{-1} ; M_{w}, 40217 \mathrm{~g} \mathrm{~mol}^{-}$ 1 ; PDI, 1.07). $M_{n}, M_{w}$ and PDI values of OSPH were found to be $825 \mathrm{~g} \mathrm{~mol}^{-1}, 1660 \mathrm{~g} \mathrm{~mol}^{-1}$ and 2.01, respectively, for $\mathrm{H}_{2} \mathrm{O}_{2}$ oxidant. Two peaks were observed with $92 \%$ of OSPH for the low molecular weight (for the first fraction: $\mathrm{M}_{\mathrm{n}}, 1635 \mathrm{~g} \mathrm{~mol}^{-1} ; \mathrm{M}_{\mathrm{w}}, 2157 \mathrm{~g} \mathrm{~mol}^{-1} ;$ PDI, $1.32)$, but $8 \%$ of its weight for the high molecular weight (for the second fraction: $M_{n}$, $8736 \mathrm{~g} \mathrm{~mol}^{-1} ; \mathrm{M}_{\mathrm{w}}, 10123 \mathrm{~g} \mathrm{~mol}^{-1}$; PDI, 1.16). 
Table 4. SEC analyses data of the synthesized compounds.

\begin{tabular}{|c|c|c|c|c|c|c|c|c|c|c|c|}
\hline \multirow[b]{2}{*}{ Compounds } & \multicolumn{3}{|c|}{ Total } & \multicolumn{4}{|c|}{ Fraction I } & \multicolumn{4}{|c|}{ Fraction II } \\
\hline & $M_{n}$ & $M_{w}$ & PDI & $M_{n}$ & $M_{w}$ & PDI & $\%$ & $M_{n}$ & $\mathbf{M}_{\mathbf{w}}$ & PDI & $\%$ \\
\hline OSPH (air) & 850 & 1155 & 1.36 & 1418 & 1650 & 1.16 & 93 & 37632 & 40217 & 1.07 & 7 \\
\hline $\begin{array}{l}\text { OSPH( } \mathrm{NaO} \\
\mathrm{Cl}) \\
(\mathrm{na}(\mathrm{NaOCl})\end{array}$ & 1436 & 1631 & $\begin{array}{c}1.14 \\
4\end{array}$ & 1436 & 1631 & $\begin{array}{c}1.14 \\
4\end{array}$ & 100 & - & - & - & - \\
\hline $\begin{array}{l}\text { OSPH } \\
\left(\mathrm{H}_{2} \mathrm{O}_{2}\right)\end{array}$ & 825 & 1660 & 2.01 & 1635 & 2157 & 1.32 & 92 & 8736 & 10123 & 1.16 & 8 \\
\hline
\end{tabular}

The electronic spectra of SPH and OSPH were recorded in THF. UV-Vis spectrum of SPH was observed with the bands at 220, 240, 287, 315 and $342 \mathrm{~nm}$. $\mathrm{K}$ band belongs to $-\mathrm{OH}$ and azomethine groups of SPH observed at 240 and $315 \mathrm{~nm}$, respectively. $B$ and $\mathrm{R}$ bands for $\mathrm{SPH}$ were observed at 287 and $342 \mathrm{~nm}$, respectively. $\mathrm{R}$ band for $-\mathrm{CH}=\mathrm{N}$ group of $\mathrm{SPH}$ was observed at $342 \mathrm{~nm}$. UV-Vis spectrum of $\mathrm{OSPH}$ was observed with the same bands at 221, 241, 291 and $346 \mathrm{~nm}$. K bands for $-\mathrm{OH}$ and azomethine groups of OSPH were observed at 241 and $291 \mathrm{~nm}$, respectively. R band for $-\mathrm{CH}=\mathrm{N}$ group of $\mathrm{OSPH}$ was seen at $346 \mathrm{~nm}$.
FT-IR spectrum of SPH (Figure 2) shows the characteristic peaks of the functional groups for SPH. Phenolic $\mathrm{O}-\mathrm{H}$ stretching and secondary $\mathrm{N}-\mathrm{H}$ stretching frequencies were observed at $3470 \mathrm{~cm}^{-1}$ and $3300 \mathrm{~cm}^{-1}$, respectively. The peak at $2980 \mathrm{~cm}^{-1}$ was attributed to the aromatic $-\mathrm{C}-\mathrm{H}$ stretching frequency. The peak for imine $(-\mathrm{HC}=\mathrm{N}-)$ group was observed at $1615 \mathrm{~cm}^{-1}$. Aromatic $-\mathrm{C}=\mathrm{C}$ stretching and the sharp peak attributed to the $\mathrm{N}-\mathrm{H}$ bending in the molecular structure of $\mathrm{SPH}$ were observed at $1580 \mathrm{~cm}^{-1}$ and $1380 \mathrm{~cm}^{-1}$, respectively. The results confirm the structure of Schiff base containing an imine $(-\mathrm{HC}=\mathrm{N}-)$ bond in the structure of SPH.

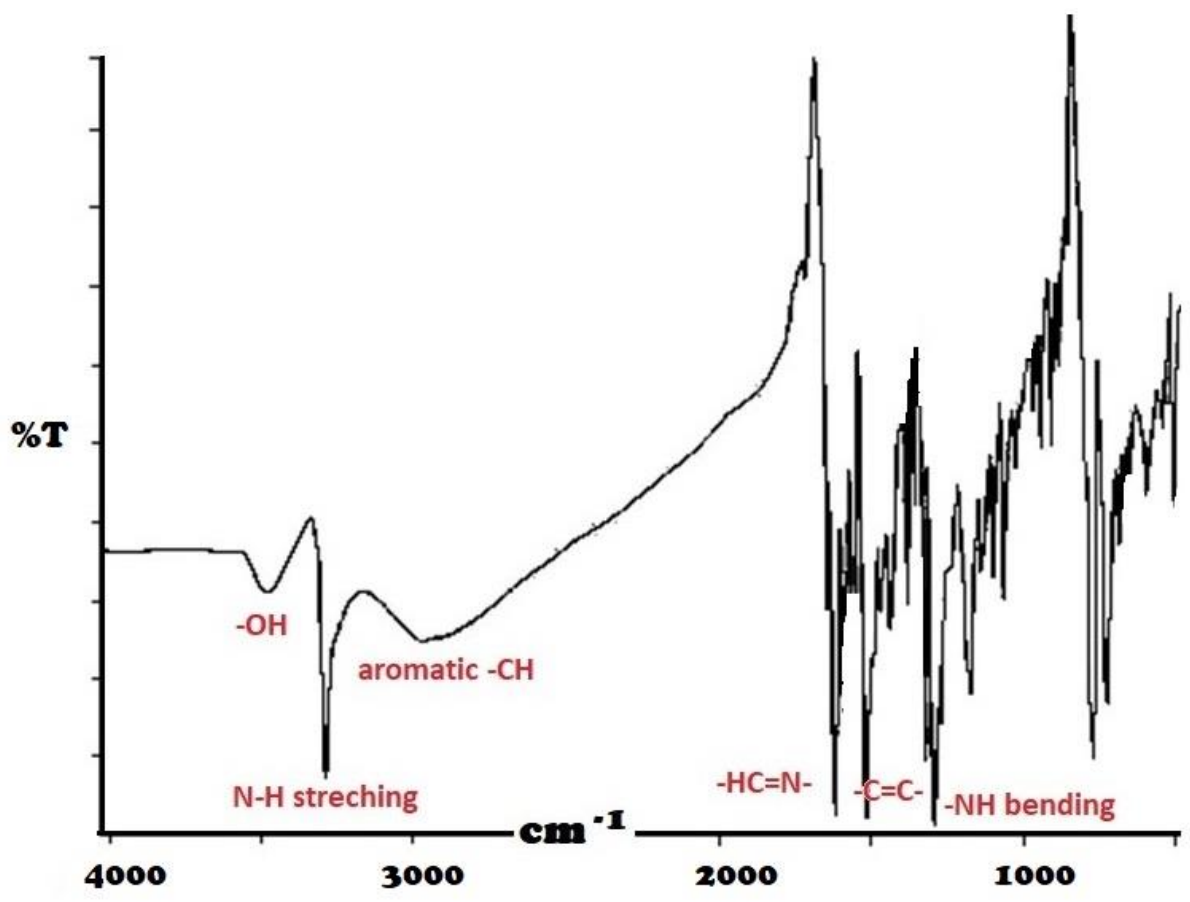

Figure 2. FT-IR spectrum of N-salicylidenehydrazone (SPH).

In the FT-IR spectrum of OSPH (Figure 3), the stretching frequencies of $-\mathrm{OH}$ and $-\mathrm{CH}=\mathrm{N}$ groups were observed at 3500 and $1600 \mathrm{~cm}^{-1}$, respectively. The characteristic peaks clearly show the binding of functional groups of the synthesized products $(10,11)$. 


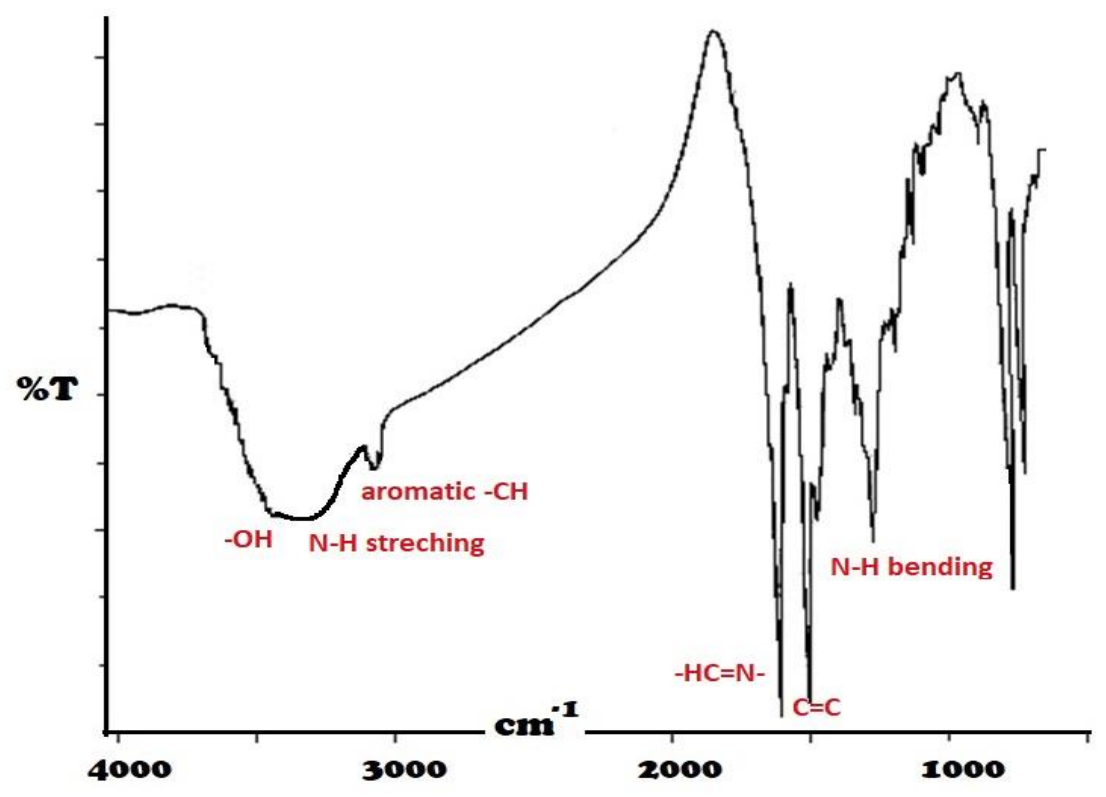

Figure 3. FT-IR spectrum of oligo-N-Salicylidenehydrazone (OSPH).

According to the spectral results and SEC analyses, OSPH's molecular structure is given as in Scheme 3. In order to identify the structures of Schiff base (SPH) and its oligomer (OSPH), ${ }^{1} \mathrm{H}-\mathrm{NMR}$ spectra were recorded in DMSO- $\mathrm{d}_{6}$. At the ${ }^{1} \mathrm{H}-\mathrm{NMR}$ spectrum of $\mathrm{SPH}$, the characteristic peaks of the functional groups were observed. Phenyl-OH group at $10.15 \mathrm{ppm}$, azomethine $(-\underline{\mathrm{CH}}=\mathrm{N})$ group at $8.30 \mathrm{ppm}$ and secondary amine ($\mathrm{N} \underline{\mathrm{H}}$ ) group at $5.60 \mathrm{ppm}$. The ${ }^{1} \mathrm{H}-\mathrm{NMR}$ and $\mathrm{FT}-$ IR results showed the formation of oligomeric macromolecules from SPH unit by the oxidative polymerization through the carbons which are ortho and para positioned to hydroxyl group. At the ${ }^{1} \mathrm{H}-\mathrm{NMR}$ spectrum of $\mathrm{OSPH}$, the characteristic peaks of the functional groups were observed. Phenyl- $\mathrm{OH}$ group at $10.40 \mathrm{ppm}$, azomethine $(-\mathrm{CH}=\mathrm{N})$ group at $9.20 \mathrm{ppm}$ and secondary amine ($\mathrm{NH}$ ) group at $6.55 \mathrm{ppm}$ (Scheme 3 ). The FTIR spectral data and the results of ${ }^{1} \mathrm{H}-\mathrm{NMR}$ spectra of OSPH confirm the formation of the synthesized molecules. The spectral results are given below the synthesis part of the compounds.



Figure 4. The structures of $\mathrm{SPH}$ and $\mathrm{OSPH}$. 


\section{Thermal analysis of OSPH}

The TG-DTA measurements of OSPH were performed under air atmosphere in the temperature range from $20^{\circ} \mathrm{C}$ to $1000^{\circ} \mathrm{C}$ in order to investigate its thermal stability. Figure 4 shows the TG-DTA curves for OSPH which was oxidatively polymerized of $\mathrm{SPH}$ in the aqueous alkaline medium by air as the oxidant. According to TG curves, OSPH started to degrade at $190{ }^{\circ} \mathrm{C}$. OSPH thermooxidatively degraded in three steps. According to TG curve of OSPH, $T_{\max }$ values were observed at 506, 625 and $820{ }^{\circ} \mathrm{C}$. $20 \%$ and $50 \%$ weight losses of OSPH were found to be at $275^{\circ} \mathrm{C}$ and $597^{\circ} \mathrm{C}$, respectively. The weight loss of OSPH was $92.56 \%$ at $1000{ }^{\circ} \mathrm{C}$. $5 \%$ weight loss in the range of $50-150^{\circ} \mathrm{C}$ assigned to water removal was also seen on TG curve of OSPH. TG-DTA analyses showed that OSPH was found to be thermally stable and resistant to thermo-oxidative decomposition.

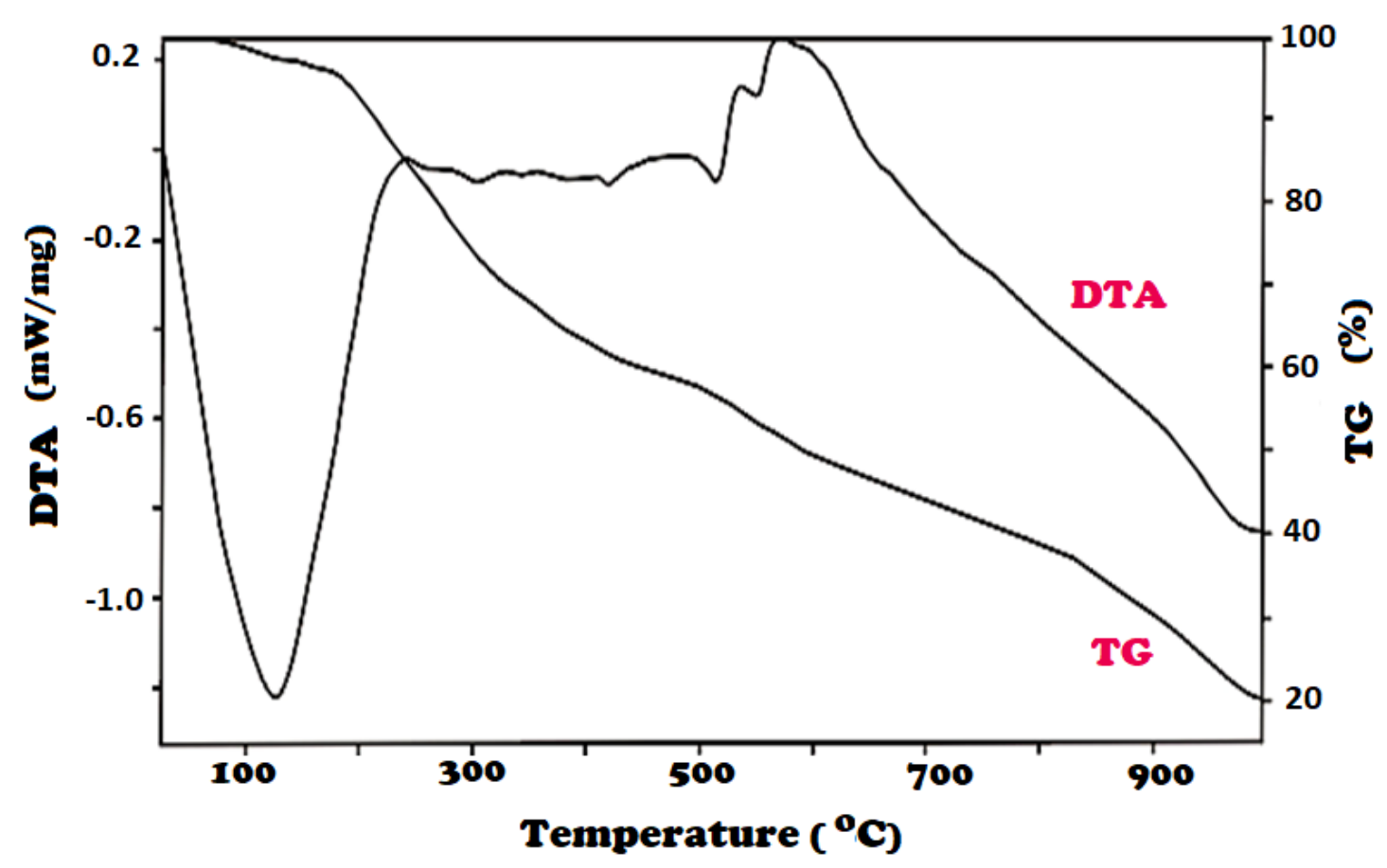

Figure 5. TG/DTA curves of oligo-N-Salicylidenehydrazone (OSPH).

\section{CONCLUSIONS}

In this study, the synthesized Schiff base (SPH) was transformed into oligo-Nsalicylidenephenylhydrazone (OSPH) using air, $\mathrm{H}_{2} \mathrm{O}_{2}$ and $\mathrm{NaOCl}$ as oxidants in an aqueous alkaline medium. According to spectral analyses, the synthesized oligo-Nsalicylidenephenylhydrazone oligomer was confirmed by bonding units through ortho and para carbons to hydroxyl group of $\mathrm{N}$ salicylidenephenylhydrazone. $M_{n}, M_{w}$ and PDI values of OSPH were found to be $1436 \mathrm{~g} \mathrm{~mol}^{-}$ $1,1631 \mathrm{~g} \mathrm{~mol}^{-1}$ and $1.14 ; 850 \mathrm{~g} \mathrm{~mol}^{-1}, 1155 \mathrm{~g}$ $\mathrm{mol}^{-1}$ and $1.36 ; 825 \mathrm{~g} \mathrm{~mol}^{-1}, 1660 \mathrm{~g} \mathrm{~mol}^{-1}$ and 2.01, respectively, for $\mathrm{NaOCl}$, air and $\mathrm{H}_{2} \mathrm{O}_{2}$ oxidants. Based on TG analysis OSPH in the aqueous alkaline medium with air oxidant, carbonaceous residue value of $\mathrm{OSPH}$ was found to be $7.44 \%$ at $1000^{\circ} \mathrm{C}$.

\section{ACKNOWLEDGMENTS}

The author thanks Prof. Dr. İsmet Kaya for his valuable comments on instrumental analyses results.

\section{REFERENCES}

1. Katon JE, editor. Organic Semiconducting Polymers. Marcel Dekker: New York, NY, USA, 1968.

2. El-Shekeil AG, Al-Yusufy FA, Saknidy S. Synthesis and characterization of some soluble conducting polyazomethine polymers. Polym. Int. 1997;44:78-82.

3. Diaz FR, Moreno J, Tagle LH, East GA. Radic, D. Synthesis, characterization and electrical properties of polyimines derived from selenophene. Synthetic Met. 1999;100:187193.

4. Ragimov AV, Mamedov BA, Yasamova SY. New efficient dielectric and antistatic materials 
based on oligoaminophenols. Polymer 1997;43:343-347.

5. Kaliyappan T, Kannan P. Co-ordination polymers. Prog. Polymer Sci. 2000;25:343370.

6b Kaya İ, Demir HÖ, Vilayetoğlu AR. The synthesis and characterization of planar oligophenol with Schiff base substituent. Synthetic Met. 2002;126:183-191.

7. Kaya İ, Cihangiroğlu N. Synthesis, characterization and anti-microbial activity of oligo-N-2-aminopyridinylsalicylaldimine and some oligomer-metal complexes. J. Poly. Res. 2004; 11:37-42.

8. Fakhari AR, Khorrami AR, Naeimi $H$. Synthesis and analytical application of a novel tetradentate $\mathrm{N}_{2} \mathrm{O}_{2}$ Schiff base as a chromogenic reagent for determination of nickel in some natural food samples. Talanta 2005;66:813-817.
9. Grigoras M, Catanescu CO. Imine oligomers and polymers. J. Macromol. Sci-Pol R 2004;C44:131-173.

10. Ayyagari MS, Marx KA, Tripathy SK, Akara JA, Kaplan DL. Controlled free-radical polymerization of phenol derivatives by enzyme-catalyzed reactions in organic solvents. Macromolecules 1995;28:51925197.

11. Kaya İ, Gökpınar M, Kamacı M. Reaction Conditions, Photophysical, Electrochemical, Conductivity, and Thermal Properties of Polyazomethines. 2017;25:739-748. Macromol.

Res.

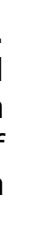

